\title{
Improving job performance through strengthening the organizational culture and interpersonal communication
}

\author{
Widodo Sunaryo $^{\left.1^{*}\right)}$, Nancy Yusnita ${ }^{2}$, Mustofa Mustofa ${ }^{3}$ \\ ${ }^{123}$ Universitas Pakuan, Bogor, Indonesia.
}

\begin{tabular}{l}
\hline Article Info \\
\hline Article history: \\
Received Jul 11th, 2020 \\
Revised Aug 05th, 2020 \\
Accepted Sep 09th, 2020
\end{tabular}

\section{Keyword:}

Teacher's job performance

Organizational culture

Interpersonal communication

SITOREM analysis

\begin{abstract}
The teacher's job performance is one of the important factor that influence the process of achieving educational goals. Maintaining and increasing teacher's job performance become urgent and important parts in educational processes. When we found in certain district that the teachers' job performance were in low level condition, we realized that we need to study the problem and to find out the way to improve teacher's job performance. This study designed as a quantitative research used sample of 200 teachers derived by random sampling from its population, and used questionnaires as instruments to collect research data. The Correlational and SITOREM Analysis used to analyze the data. The research had generated findings that the school Organizational Culture and teacher's Interpersonal Communication as partially and simultaneously had strong significant correlations with job performance. It had been found also that some dimensions of school Organizational Culture and teacher's Interpersonal Communication were recommended as high-level priority to be strengthened in order to improve teacher's job performance.
\end{abstract}

Corresponding Author:

Widodo Sunaryo

Universitas Pakuan

Email: widodos.unpak@yahoo.com

(C) 2020 The Authors. Published by the Indonesian Institute for Counseling,

Education, and Therapy (IICET). This is an open-access article under the CC BY license (https://creativecommons.org/licenses/by/4.0/)

\section{Introduction}

Teacher's job performance become as a determinant factor in generating output or outcomes in the educational process. Unfortunately, based on the 2015 National Teacher Competence Evaluation Report, it had been found that teachers from South Tangerang got low score (5.6) in a competence test compared with another teachers' score from other cities in Province of Banten. This test result reflects that there is a phenomena of low level of teacher's job performance in South Tangerang Banten. Based on that phenomena, it is important to find out what the problem of teacher's job performance and what factors that influenced the job performance. This research is conducted in order to understand the problem of teacher's job performance and to propose the way to improve teacher's job performance. Considering of that, we proposed some steps to conduct the research. The first step to conduct a preliminary survey in order to get early indications about teacher's performance. The Survey generated some findings as follows: $39.9 \%$ of teachers had problem in quantity of work that should be finished in his/her formal schedule, $34.9 \%$ of teachers had problem in quality of work that should be achieved, $43.3 \%$ of teachers that had low efficiency of work, $46.6 \%$ of teachers that worked ineffective way, and $44.9 \%$ of teachers had low productivity. Those preliminary survey findings showed an indication of teacher's job performance problem. The second step is to find variables were assumed had a relationship with teacher's job performance. The third step is to identify the dimensions of each variables 
that had high priority to be strengthened in order to formulate an effective improvement program to increase teacher's job performance.

(Schein, 2010) defined organizational culture as a pattern of shared basic assumptions learned by a group as it solved its problems of external adaptation and internal integration, therefore, to be taught to new members as the correct way to perceive, think, and act in relation to his/her tasks or job. Employee performance can be seen as attitudes and contributions to the achievement of task performance (Colquitt, Lepine and Wesson, 2015). Employee performance related to attitude and behavior on tasks or activities or achievement, usually associated with employee attempts to think, to feel, and to act something for a certain amount his/her tasks or job (Luthan, 2011).

Research had indicated that there was a positive and significant relationship between organizational culture and performance $(r=0.552 \mathrm{p}<0.01)$ (Lambok Simamora, Billy Tunas and Widodo Sunaryo, 2016). Also (Nadiyah, Soewarto Hardhienata and Widodo Sunaryo, 2018) had a similar finding that there was a positive and significant relationship between organizational culture and performance $(\mathrm{r}=0.614 \mathrm{p}<0.01)$. Another research had similar finding that organizational culture and teacher's job performance had a positive and significant relationship $(r=0.616 \mathrm{p}<0.01)$ (Zamroni et al., 2019). Again similar research finding that there was a positive strong relationship $(r=0.756, p<0.01)$ between organizational culture and job performance (Nancy Yusnita, Elly Rusdiawaty and Widodo Sunaryo, 2019).

Interpersonal communication as selective, systemic, unique, processual (is an ongoing process) transactions that allow people to reflect and build personal knowledge of one another and create shared meanings (Wood, 2010). The key terms in this definition that to make an effective interpersonal communication have to refer to the whole individual aspects being involved, and to an ongoing processes including sending, receiving and feedback processes. The way we communicate with people who use our service or facility also has a direct impact on how care is perceived and experienced (Pavord and Donnelly, 2015). We refer to this as interpersonal communication and there are particular skills that are needed to ensure that we are communicating effectively in social care settings. Interpersonal communication refers to a limited number of people who are usually in proximity to each other, use many sensory channels, and are able to provide immediate feedback. The interpersonal communication forms used by employees on the job will influence their job performance (Hellriegel and Slocum, 2011).

Research finding showed that there was a functional relationship between interpersonal communication with teacher performance $(r=0.755 \mathrm{p}<0.01)$ (Kun Nurachadijat, Soewarto Hadhienata, Widodo Sunaryo, 2017). There is research a finding that a strong enough relationship between employee interpersonal communication with their job performance $(r=0.602 \mathrm{p}<0.01)$ (Moghimi, Chamanzamin and Shaghaghi, 2013). Also that there was a positive relationship $(r=0.377, p<0.05)$ between interpersonal communication with job performance (Siti Chodidjah, Billy Tunas, Rita Retnowati, 2017).

\section{Method}

The research used a quantitative approach consist of Correlational and SITOREM Analysis. The research population are 741 permanent teachers coming from 21 State Junior High School in Tangerang Selatan City. The research sample was 200 teachers taken from the population as it calculated by Slovin Formula with $95 \%$ significance level. The research framework can be described in the figure 1 .

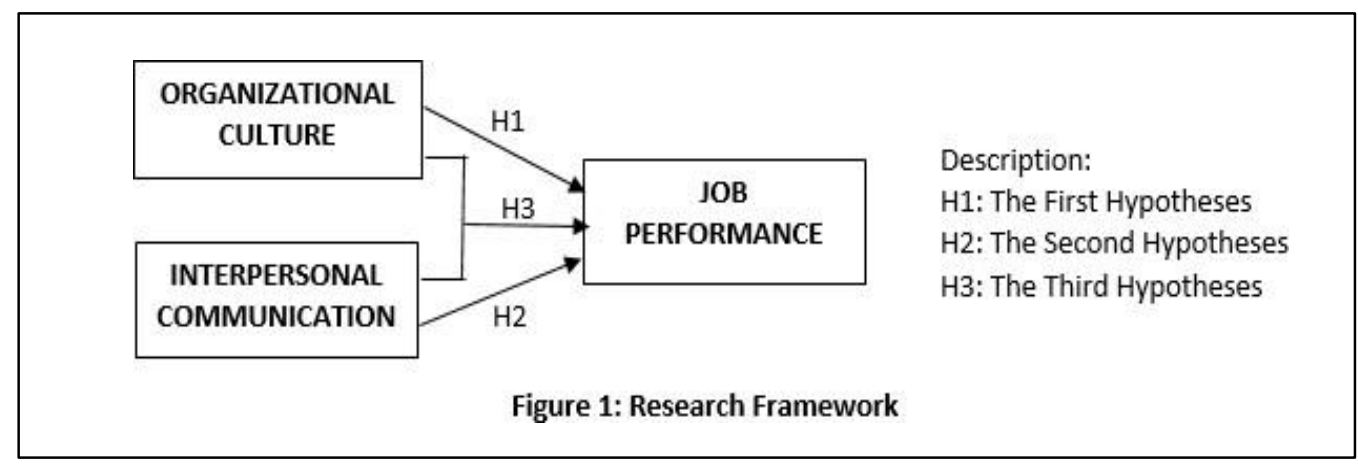

The research framework consist of 3 hypotheses. First, there is a positive relationship between organizational culture and job performance. Second, there is a positive relationship between interpersonal 
communication and job performance. Third, there is a positive relationship between organizational culture and interpersonal communication simultaneously with job performance.

Teacher's job performance measured using a questionnaire filled by each teacher's School Principal. His/her Principal rated teacher's job performance in 5 points Rating Scale. Data of school organizational culture collected using a questionnaire filled by teacher his/her-self. He/she rated his/her perception about all aspects of organizational culture in 5 points Likert Scale. Data of teacher's interpersonal communication collected using a questionnaire filled by employee. He/she rated his/her superior's leadership style in 5 points Rating Scale. All those questionnaires had already tried out (used 30 sample) to measure its items validity coefficient which calculated by Pearson's Product-Moment Correlation formula, and the questionnaires reliability coefficient calculated by Cronbach Alpha's formula (Sekaran and Bougie, 2013; Nolan and Heinzen, 2012).

Table 1: Reliability Coefficient of the Questionnaires.

\begin{tabular}{clccc}
\hline No & \multicolumn{1}{c}{ Questionnaires Measured } & Items & Rated By & Reliability \\
\hline $\mathbf{1}$ & Teacher's Job Performance & 32 & School Principal & $\mathbf{0 . 9 4 3}$ \\
$\mathbf{2}$ & School's Organizational Culture & 31 & Teachers & $\mathbf{0 . 9 2 5}$ \\
\hline $\mathbf{3}$ & Teacher's Interpersonal Communication & $\mathbf{3 0}$ & Teacher & $\mathbf{0 . 9 3 8}$ \\
\hline
\end{tabular}

Notes: All questionnaires before validation trial each consisted of 40 items. Some item were dropped-out, and the rest is the valid items only. Validation process of those questionnaires used Item Analysis

Procedure (Item-Total Scores Correlation calculated by Pearson Product Moment Correlation at 0.05

Level of Significance).

All those questionnaires applied to 200 teachers as the research sample analyzed step by step. First, testing the normality of empirical data from research sample used Lillifors Formula. This procedure used to examine that research sample coming from a population with normal distribution. Second, testing the linearity of empirical data from research sample used Regression Analysis. This procedure used to examine that the relationship of the data from employees' performance, organizational culture and transformational leadership meet the principle of linearity. The normality and linearity results were required to meet the requirement for using parametric statistics. Third, conducted correlational analysis to measure the strength of relationship between research variables. Fourth, used the SITOREM Analysis (SITOREM is abbreviated from "Scientific Identification Theory to Conduct Operation Research in Education Management"). The SITOREM Analysis consist of assessment process using some criteria to rank indicators of the variables from the highest to the lowest level in term of priority. The criteria used are Costs, Benefits, Urgent and Importance (CBUI). It means that indicators which had high score in CBUI criteria will have priority to be maintained, and indicators which had low score in CBUI criteria will have priority to be improved (Widodo Sunaryo and Sri Setyaningsih, 2018).

Recently, the SITOREM Analysis had already used in some researches. By using SITOREM Analysis, those researches had generated recommendation for determining the priority of indicators from research variables that had to be improved and maintained (Widodo Sunaryo, Ali M. Basroh, and Soewarto Hardhienata, 2019; Ari Rosandi, Soewarto Hardhienata, Widodo Sunaryo, and M. Zainal Arifin, 2019; Rudi Prihadi, Thamrin Abdullah, and Widodo Sunaryo, 2019; R. Agus Sriyanta, Didik Notosudjono, Bibin Rubini, 2019). In this research, each indicator of research variables were scored by CBUI criteria. Job Performance indicators are efficiency, effectiveness, quantity, quality and Productivity. Organizational Culture indicators are symbols, story, ritual, value, philosophy, and assumption. Interpersonal Communication indicators are sending-receiving information, feedback, empathy, open mindedness, trust and supportiveness.

\section{Results and Discussion}

Normality Test for Empirical Data from Research Sample can be described in table 3. Based on Normality Test results above mentioned where empirical data is lower than Lillifors Standard, it can be concluded that scores from each questionnaires of employees' performance, Organizational Culture and Transformational Leadership, coming from a population with a normal distribution. It means that this result meet one of the requirement for analyzing sample data to generate conclusion of the population. 
Table 3. Normality Test Results

\begin{tabular}{llccc}
\hline No & Description & Job Performance & $\begin{array}{c}\text { Organizational } \\
\text { Culture }\end{array}$ & $\begin{array}{c}\text { Interpersonal } \\
\text { Communication }\end{array}$ \\
\hline $\mathbf{1}$ & Empirical Data & 0.0297 & 0.0346 & $\mathbf{0 . 0 2 7 1}$ \\
$\mathbf{2}$ & Lillifors' Standard & 0.0626 & 0.0626 & $\mathbf{0 . 0 6 2 6}$ \\
\hline $\mathbf{3}$ & Results & Empirical < Standar & Empirical < Standar & Empirical < Standar \\
\hline
\end{tabular}

Based on Normality Test results above mentioned where empirical data is lower than Lillifors Standard, it can be concluded that scores from each questionnaires of employees' performance, Organizational Culture and Transformational Leadership, coming from a population with a normal distribution. It means that this result meet one of the requirement for analyzing sample data to generate conclusion of the population.

Linearity Test used to examine that the relationship between Organizational Culture with Job Performance, and between Interpersonal Communication with Job Performance, should meet the standard linear regression, as described on table 4.

Table 4: Linearity Test Results

\begin{tabular}{clcc}
\hline No & \multicolumn{1}{c}{ Descriptions } & $\begin{array}{c}\text { Relationship between } \\
\text { Organizational } \\
\text { Culture with Job } \\
\text { Performance }\end{array}$ & $\begin{array}{c}\text { Relationship between } \\
\text { Interpersonal } \\
\text { Communication with } \\
\text { Job Performance }\end{array}$ \\
\hline $\mathbf{1}$ & Deviation from Linearity $($ empirical $)$ & 1.046 & $\mathbf{1 . 1 2 7}$ \\
$\mathbf{2}$ & Standard of Significance $(\mathrm{p}<0.05)$ & 1.420 & $\mathbf{1 . 4 0 0}$ \\
\hline $\mathbf{3}$ & Results & Empirical < Standard & Empirical $<$ Standard \\
\hline
\end{tabular}

Based on Linearity Test Results above mentioned where empirical deviation from linearity is lower than the standard of significance level $(\mathrm{p}<0.05)$, it can be concluded that the relationship between organizational culture with job performance and between interpersonal communication with job performance followed the regression linearity principle. It means that this result meet one of the requirement for analyzing sample data to generate conclusion of the population.

Correlational Analysis Results. The correlational analysis technique used to test the hypotheses. This analysis used Product-Moment Correlation Formula and applied t-test procedure with 0.05 minimum level of significance, as described in the table 5.

Table 5. Correlation Analysis Results

\begin{tabular}{|c|c|c|c|c|}
\hline No & Description & $\begin{array}{c}\text { The Relationship between } \\
\text { Organizational Culture } \\
\text { with Job Performance }\end{array}$ & $\begin{array}{l}\text { The Relationship between } \\
\text { Interpersonal } \\
\text { Communication with Job } \\
\text { Performance }\end{array}$ & $\begin{array}{l}\text { The Relationship between } \\
\text { Organizational Culture and } \\
\text { Interpersonal Communication } \\
\text { simultaneously with Job } \\
\text { Performance }\end{array}$ \\
\hline 1 & $\begin{array}{l}\text { Coefficient } \\
\text { Correlation }\end{array}$ & 0.603 & 0.447 & 0.728 \\
\hline 2 & Empirical $t$ Score & 10.797 & 7.028 & 17.511 \\
\hline 3 & $\begin{array}{l}\text { Standard } t \text { Score } \\
(\mathrm{p}<0.05)\end{array}$ & 2.570 & 2.570 & 3.040 \\
\hline 4 & Results & Empirical < Standard & Empirical < Standard & Empirical < Standard \\
\hline
\end{tabular}

Based on Correlational Analysis Results above mentioned, it can be concluded that all research hypotheses accepted. The present correlation coefficient of organizational culture with job performance $(r=0.603)$ had similar positive direction compared with prior related research. The present correlation coefficient of interpersonal communication with job performance $(r=0.447)$ had similar positive direction with prior related research. The present correlation coefficient between organizational culture and interpersonal communication simultaneously with job performance $(r=0.728)$ can be interpreted that a simultaneous work of organizational culture and interpersonal communication had a synergized effect toward job performance. 
SITOREM Analysis Results. By using SITOREM Analysis, each indicator of research variable scored based on CBUI Criteria (Cost, Benefit, Urgent and Important). The result of SITOREM Analysis described by the rank-order of priority which indicators recommend to be improved or to be maintained in each variable as described in table below.

Table 6. SITOREM Analysis Results (5 Lowest and Highest Scores only)

\begin{tabular}{clll}
\hline $\begin{array}{c}\text { Rank-Order } \\
\text { of Priority }\end{array}$ & \multicolumn{1}{c}{ Variable and Indicator } & Score & Action Recommended \\
\hline $\mathbf{A}$ & Organizational Culture & 3.2 & To be Improved \\
$\mathbf{1}$ & Philosophy & 3.3 & $\begin{array}{l}\text { To be Improved } \\
\text { To be Improved }\end{array}$ \\
$\mathbf{2}$ & Story & 3.3 & To be Improved \\
$\mathbf{3}$ & Assumption & 3.4 & \\
$\mathbf{4}$ & Value & 3.5 & \\
$\mathbf{5}$ & Symbols & & To be Improved \\
& & 3.2 & To be Improved \\
$\mathbf{B}$ & Interpersonal Communication & 3.4 & To be Improved \\
$\mathbf{1}$ & Level of Position & 3.4 & To be Improved \\
$\mathbf{2}$ & Feedback & 3.6 & \\
$\mathbf{3}$ & Positive Action & 4.1 & \\
$\mathbf{4}$ & Empathy & & To be Improved \\
$\mathbf{5}$ & Openness & 3.4 & To be Improved \\
& & 3.4 & To be Improved \\
$\mathbf{C}$ & Job Performance & 3.6 & To Maintained \\
$\mathbf{1}$ & Effectiveness & 4.1 & To be Maintained \\
$\mathbf{2}$ & Efficiency & $\mathbf{4 . 2}$ & \\
$\mathbf{3}$ & Productivity & Quality &
\end{tabular}

\section{Conclusion}

This research has examined the 3 hypotheses and generated 3 findings. First, there is a positive, significant and strong relationship between school's organizational culture with teacher's job performance. It means that any effort to strengthening the school organizational culture can be predicted will improve teacher's job performance. Second, there is a positive, significant and moderate relationship between teacher's interpersonal communication with teacher's job performance. It means that any effort to improve the teacher's interpersonal communication can be predicted will moderately improve teacher's job performance. Third, there is a positive, significant and strong relationship between organizational culture and teacher's interpersonal communication simultaneously with teacher's job performance. It means that any effort to strengthening simultaneously both school organizational culture and teacher's interpersonal communication can be predicted will improve teacher's job performance. Based on the SITOREM Analysis Results it can be formulated some specific recommendations to each variables. First, the school's organizational culture should be improved by strengthening the school philosophy (way of life), the story of organization (image and reputation), the basic underlying assumption (way of thinking), the value of teacher's job (job attractiveness, proudness), and the symbol (teacher's status and identity). Second, the interpersonal communication among teacher, principal, and others should be improved by increasing feedback, empathy, openness, and positive action while doing interpersonal communication, and also teacher should be confident about his position as a teacher. Third, the job performance indicators should be improve by increasing effectiveness, efficiency and productivity in teaching activities, and also the quality and quantity of teaching work achieved should be continuously maintained. 


\section{References}

Colquitt, J.A., J.A. Lepine, J.M. Wessons. 2015. Organizational Behavior: Improving Performance and Commitment in the Workplace. New York McGraw-Hill.

Hellriegel, D. and J. W. Slocum, Jr. (2011). Organizational Behavior. Mason, OH: CengageLearning.

Luthan, F. Organizational Behavior: An Evidence-Based Approach. (2011). New York: Mc-Graw- Hill.

Moghimi, S.F., Mousa Rezvani Chamanzamin, and Ali Maghsoodi Shaghaghi. "The Relationship between Communication Skills and Job Performance of the Employees, Fire Managers of

Rasht City". (2013). International Journal of Business and Behavioral Sciences Vol. 3, No. 2, pp. 60-79.

Nadiyah, Soewarto Hardhienata and Widodo Sunaryo. "Sequential explanatory analysis on lecturer' performance investigated by reference to organizational culture, knowledge management, and personality". (2018). International Journal of Multidisciplinary Education and Research, Volume 3, Issue 3, pp. 100-102.

Nancy Yusnita, Ely Rusdiawati and Widodo Sunaryo. "Studying the Relationship between Organizational Culture and Transformational Leadership with Employees' Performance". (2019). International Journal of Latest Engineering and Management Research (IJLEMR), Volume 04, Issue 10, pp. 01-07.

Nurachadijat, K., Soewarto Hadhienata, and Widodo Sunaryo. "Analysis of Sequential Explanatory of Teacher's Performance Reviewed from Transformational Leadership, Job Engagement, and Interpersonal Communication". (2017). International Journal of Managerial Studies and Research (IJMSR), Volume 5, Issue 9, pp. 24-29.

Pavord, E., and E. Donnelly. Communication and Interpersonal Skills. (2015). Banbury, UK: Lantern Publishing Limited.

Robbins, S.P., and T.A. Judge. Essentials of Organizational Behavior. (2013). New York: McGraw- Hill.

Schein, E.H. Organizational Culture and Leadership. San Francisco, CA: John Wiley \& Sons, 2010. Schermerhorn, Jr. J.R., J. G. Hunt, R. N. Osborn, and M. Uhl-Bien. (2010). Organizational Behavior. Hoboken, NJ: John Wiley \& Sons.

Simamora, L., Billy Tunas and Widodo Sunaryo. (2016). "Relationship between Organizational Culture, Emotional Intelligence and Job Satisfaction to Lecturers' Performance". International Journal of Managerial Studies and Research (IJMSR) Volume 4, Issue 11, pp. 99-105.

Siti Chodidjah, Billy Tunas, and Rita Retnowati. "The Relationship between, Transformational Leadership, Organizational Culture and Interpersonal Communication to Teachers' Performance". (2017). International Journal of Managerial Studies and Research (IJMSR) Volume 5, Issue 4, pp. 35-41.

Wood, Julia T. Interpersonal Communication: Everyday Encounter. (2010). Boston, MA: Cengage Learning.

Zamroni, Soewarto Hardhienata, Widodo Sunaryo, M. Zainal Arifin, and Zenal Abidin. (2019). "Improving Teacher Performance by Strengthening Personality, Organizational Culture, and Achievement Motivation". Opcion, Año 35, Especial No 22: 2899-2921, ISSN 1012-1587/ISSNe: 2477-9385. 